\title{
The experience of therapy by therapists and survivors after exposure to armed robbery
}

\author{
SJ Marais, D.Cur (Psychiatric Nursing), Department of Nursing Science, Rand \\ Afrikaans University \\ M Poggenpoel, Ph.D, Department of Nursing Science, Rand Afrikaans University \\ $\mathrm{CPH}$ Myburgh, DEd, Department of Educational Sciences, Rand Afrikaans \\ University.
}

\section{Abstrak}

In hierdie artikel word die resultate bespreek van navorsing wat gedoen is om vas te stel wat die belewenis van terapie is deur onderskeidelik die oorlewende van gewapende roof en die terapeut van die oorlewende van gewapende roof, waar terapie voortydig deur die oorlewende van gewapende roof gestaak word. 'n Hoë persentasie van terapie vir die oorlewende van gewapende roof word voortydig deur die oorlewende van gewapende roof gestaak en lei daartoe dat die indiwidu wat aan hierdie tipe van geweld blootgestel was, nie al die moontlike geleenthede tot herstel kan benut nie. Die navorsingsvrae wat hieruit ontstaan het is: "Hoe beleef oorlewendes van gewapende roof terapie nadat hulle blootgestel was aan 'n gewapende roof?" en "Hoe beleef terapeute terapie met die oorlewende van gewapende roof?" 'n Kwalitatiewe, verkennende, beskrywende en kontekstuele navorsingsontwerp is gebruik. Fenomenologiese, semi-gestruktureerde onderhoude is met oorlewendes van gewapende roof en terapeute gevoer ten einde hulle belewenisse te verken en beskryf. Daar is bevind dat terapie tot belewenisse van woede, vrees, hartseer en vrede lei. Die behoeftes van oorlewendes van gewapende roof wat gedurende terapie geïdentifiseer is, is behoeftes aan omgee, beskikbaarheid, empatie, luister, fokus op die gewapende roof, hulp met hantering van probleme, 'n vertrouensverhouding met die terapeut, sensitiwiteit deur die terapeut en omgee deur belangrike ander vir die oorlewende van gewapende roof. Hierdie behoeftes is deur beide die groepe geïdentifiseer. Wanneer daar nie in dié behoeftes voorsien word nie, word terapie voortydig gestaak en as onsuksesvol beleef. Drie beginsels vir terapie is ook geïdentifiseer, naamlik terapie moet so gou moontlik ' $n$ aanvang neem, die verloop en tegniek moet verduidelik word en simptome wat verwag word moet verduidelik word.

\section{Abstract}

In this article the results of research undertaken to explore the experience of therapy by respectively the survivor of armed robbery and the therapist of the survivor of armed robbery in the case where therapy is prematurely terminated by the survivor of armed robbery are discussed. A high percentage of therapy for the survivor of armed robbery is being terminated prematurely by the survivor. This might be the reason for failing to use all possible opportunities to recover within reasonable time. The research questions that arouse are: "How do survivors of armed robbery experience therapy after being exposed to armed robbery?" and "How do therapists experience therapy for the survivor of armed robbery?" A qualitative, exploratory, descriptive and contextual research design was utilised. Phenomenological, semi-structured interviews were conducted with survivors of armed robbery and therapists of survivors of armed robbery to explore and describe their experiences. It was found that therapy leads to the experience of anger, fear, sadness and peace. The following needs of the survivor of armed robbery in the course of therapy were identified: a need to be cared for, availability, empathy, listening, focus on the armed robbery, help with the handling of problems, a trustworthy relationship with the therapist, sensitivity by the therapist and caring by important others in the life or the survivor of armed robbery. These needs were identified by both groups of participants. When these needs are not met within therapy, therapy is terminated prematurely and experienced as unsuccessful. Three principles of therapy were identified, namely that therapy should start as soon as possible, the trend and technique should be explained and signs and symptoms should be explained. 


\section{Background and orientation}

In the past five years armed robbery escalated dramatically according to the numbers published thereof. From January to June 1997 a total number of 3896 armed robberies were referred to court (Bothma, 1997:3). Within two days in September 1999 five cash-in-transit robberies took place in and around Johannesburg (Steenkamp, 1999:2). From January 1997 between 244 and 351 cases of armed robbery of vehicles are reported per month (Van Zyl, 1999b:14). It is no wonder that South Africa's budget for safety and security for 1997 represent a $15 \%$ increase compared to the figures of 1996 (Thiel, 1997:2).

The results of the increase in numbers of armed robberies are not only seen in the effects on budgets but more specifically on the experiences of the individual, family and community after exposure to armed robbery.

\section{Individuals reported experiences of:}

- fear for the future and revenge

- loss of work

- emotional harm

- a feeling of being threatened while victims are tied up and burned with an iron

- $\quad$ exposure to dangers of nature while a victim is tied up and thrown into a mealieland to hope for help the next day

- $\quad$ being jumped on and thrown with stones when being victimised by armed robbers and thereafter (Moya, 1998:2; Sapa, 1998:4; Sapa, 1998:3; Smith, 1999:11; Van Zyl, 1999a:3; Van Niekerk, 1999:15; Van Wyk, 1999:6; Vapi, 1998a:2; Vapi, 1998b:2).

The tendency of mental health problems due to exposure to life-threatening situations increases in the same ratio to the increase of these situations (Rautenbach, 1997:10). In a study where one thousand and seven respondents were used, it was found that a $39,1 \%$ chance exist that a person exposed to a traumatic situation would become mentally ill because of it (Davis \& Breslau, 1994:290).

Healthcare by means of therapy is usually recommended, as it can save expensive expenditures for medication and admission when a mental health problem is left to become worse (Davis \& Breslau, 1994:290).

Premature termination of therapy was observed by $77 \%$ of clients exposed to group therapy and $32 \%$ of clients exposed to individual therapy (Allen \& Bloom, 1994:433).

\section{Problem statement and research objectives}

The researcher and fellow therapists found that survivors of armed robbery do not complete therapy. This might be the reason for failing to use all possible opportunities to recover within a reasonable time and may even lead to a need for more aggressive, expensive types of therapy like medication and admission.

The following questions arouse: "How do survivors of armed robbery experience therapy after being exposed to armed robbery?" and "How do therapists experience therapy for the survivor of armed robbery?"

The objectives of this research were to explore and describe the experience of survivors of armed robbery and their therapists of therapy after the armed robbery to understand why therapy is terminated prematurely.

\section{Research design and method}

A qualitative, exploratory, descriptive and contextual research design was utilised (Schurink, 1998:240,280; De Vos \& Fouché, 1998:80). In the first step of the research phenomenological, semi-structured interviews were conducted with survivors of armed robbery who terminated therapy prematurely as well as with therapists of survivors of armed robbery where the survivors terminated therapy prematurely. Interviews were transcribed verbatim. Field notes were taken down in the course of the interviews and thereafter. Two coders then analysed the raw data and followed it up with consensus interviews as directed by Tesch (in Creswell, 1994:152).

The population for this research consisted of survivors of armed robbery as well as the therapists of the survivors of armed robbery. Purposive sampling was done based on the criteria of:

- Survivors of armed robberies that terminated therapy prematurely and were not admitted to hospital

- Therapists of survivors of armed robbery who were exposed to the situation where the survivor of the robbery terminated therapy prematurely

- Male and female participants in each of the two groups

- Participants that speak Afrikaans or English

- Participants of eighteen years and older

\subsection{Ethical considerations (Medical Research Council, n.d.:4-6)}

Participants were invited to take part in this research project voluntarily. They were assured that they could withdraw at any time without penalty. All information regarding the research were provided to possible participants so that they could give their informed consent. Measures to ensure anonymity and confidentiality were described. No names were used in the interviews. The audio taped recordings of the interviews were kept under lock and key and were destroyed after the verbatim transcription of the interviews. The telephone number of a counsellor was provided for participants needing support after the research interview. 
The researcher also undertook to provide feedback on the research results to those participants requesting it.

\section{Measures for ensuring trustworthiness}

Throughout the research Guba's model for trustworthiness as described in Lincoln \& Guba (1985:289-331) was used.

The four criteria used were:

- truth-value

- applicability

- consistency and

- $\quad$ neutrality (Krefting, 1991:214-222).

Truth-value was ensured by utilising the strategy of credibility and applicability by applying the strategy of transferability. Consistency was ensured through the use of the strategy of dependability. Neutrality was obtained by applying the strategy of confirmability.

Table 1 is a summary of the strategies used to obtain trustworthiness.

\section{Data-collection}

Phenomenological interviews were conducted with participants by the researcher. The research question posed to survivors of armed robberies was: "Tell me about your experience of therapy after being exposed to an armed robbery". The question to therapists of survivors of armed robbery was: "Tell me about your experience of therapy with survivors of armed robbery". If it did not come naturally, participants were asked about the experience they had with premature termination of therapy by the survivor of armed robbery.

The participants were lead to tell their experience in a narrative style with the least possible disruption and the use of non-verbal techniques like nodding, minimal verbal responses, paraphrasing, open-ended questions, reflection of feelings and a summary at the end of the interview (Hollway \& Jefferson, 2000:31; Okun, 1987: 76-77).

During the course of the interviews and thereafter, field notes were written by the researcher (Woods \& Catanzaro, 1988: 283). The interviews were verbatim transcribed to enable coders to analyse the data.

\section{Data analysis}

The data were analysed by two coders separately from each other, the independent coder being a psychiatric specialist with experience of coding of qualitative research, and the researcher self.

A protocol for coding was described and supplied to the independent coder. The protocol was also adhered to by the researcher. Steps that had to be followed were:

- $\quad$ Read through interview transcriptions and field notes to get an overview or listen to the audiotapes. Jot important ideas down.

- Choose one interview to read again and question the objective and underlying meaning. Write thoughts down.

- Repeat the abovementioned for each interview. List and group themes. Distinguish between main, unique and other themes.

- Use abbreviations and note it down in the text. Check if new themes are found.

- Describe categories and group it to identify relations between them

- Decide on final abbreviations and arrange them alphabetically

- Gather information for all categories and do a preanalysis.

- If needed recoding can be done (Tesch in Creswell, 1994:155).

Consensus discussions between the independent coder and the researcher, with follow-up discussions between the researcher and promoters were held.

A literature control was conducted to verify the results of the research. Results are described in three main categories, namely feelings experienced, needs of the survivor of armed robbery within therapy and principles of therapy. With each theme a translated quote will be given and it will be supported by some literature quotes.

\section{Results, discussion and literature control}

Phenomenological interviews were conducted by the esearcher with two groups of participants, the survivors of armed robbery and therapists of survivors of armed robbery. One pre-study interview was conducted with a survivor of an armed robbery.

Eight further interviews were conducted with survivors of armed robberies, of which four were females and four were males. The armed robberies which these individuals experienced include bank-supermarket-and other shop robberies. The participants included security staff, sales persons, as well as managers of the involved businesses. The ages of the participants varied from eighteen years to fifty five years. Three of the interviews were conducted in English and the rest were conducted in Afrikaans.

Five interviews were conducted with therapists of survivors of armed robberies. Three of these therapists were females and two were males. The therapists originated from different disciplines including psychology, social work and theology. The ages of the therapists varied from thirty years to sixty years. All the interviews were conducted in Afrikaans as that was the language of preference (Marais, 2001:38-39)

On the research questions posed to participants, both survivors of armed robbery and therapists of survivors of 
Table 1: Strategies to ensure trustworthiness

\begin{tabular}{|c|c|c|}
\hline STRATEGY & CRITERIA & APPLICATION \\
\hline \multirow[t]{6}{*}{ Credibility } & Prolonged engagement with the field & $\begin{array}{l}\text {-The researcher spent } 13 \text { years in the field of } \\
\text { psychiatric nursing and has experience of } \\
\text { qualitative research } \\
\text {-Fourteen research interviews were conducted } \\
\text {-Enough time was spent with participants to } \\
\text { comprehend their understanding of the } \\
\text { situation }\end{array}$ \\
\hline & Reflexibility & -Concensus discussion with independent coder \\
\hline & Triangulation & $\begin{array}{l}\text {-Data collection by means of verbatim } \\
\text { transcribed interviews and field notes } \\
\text {-Open coding by two coders } \\
\text {-Literature control }\end{array}$ \\
\hline & Peer examination & $\begin{array}{l}\text {-Independent coder } \\
\text {-Discussions with promoters }\end{array}$ \\
\hline & Authority of researcher & $\begin{array}{l}\text {-The researcher had a M.Cur degree and is a advanced } \\
\text { practitioner in psychiatric nursing } \\
\text {-Experience in qualitative research }\end{array}$ \\
\hline & Structural coherence & $\begin{array}{l}\text {-The focus of the interviews was only on } \\
\text { experience of therapy }\end{array}$ \\
\hline \multirow[t]{2}{*}{ Transferability } & Dense descriptions & $\begin{array}{l}\text {-Dense description of methodology and results } \\
\text { including verbatim quotations }\end{array}$ \\
\hline & Nominated sample & $\begin{array}{l}\text {-Purposive sampling of both groups, } \\
\text { representing gender, age and variety of typical } \\
\text { robberies as well as therapists from different } \\
\text { academic backgrounds }\end{array}$ \\
\hline \multirow[t]{5}{*}{ Dependability } & Dependability audit & $\begin{array}{l}\text {-Data analysis protocol supplied to an } \\
\text { independent coder } \\
\text {-Independent coding by two experts }\end{array}$ \\
\hline & Dense descriptions of inethodology & -Methodology description of high quality \\
\hline & Triangulation & $\begin{array}{l}\text {-Fourteen verbatim transcribed interviews and } \\
\text { field notes were used } \\
\text {-Independent coder and researcher coded } \\
\text { separately and held consensus discussions } \\
\text {-Open coding method }\end{array}$ \\
\hline & Peer examination & $\begin{array}{l}\text {-Independent coder used } \\
\text {-Frequent discussions with the promoters who are ex- } \\
\text { perienced in the field of research and therapy }\end{array}$ \\
\hline & Code-recode process & $\begin{array}{l}\text {-The researcher and independent coder analysed raw } \\
\text { data separately and identified categories of informa- } \\
\text { tion in consensus discussion }\end{array}$ \\
\hline \multirow[t]{2}{*}{ Confirmability } & Confirmability & -This was possible through the keeping of all records \\
\hline & $\begin{array}{l}\text { Triangulation } \\
\text { Reflexivity }\end{array}$ & $\begin{array}{l}\text {-As discussed } \\
\text {-As discussed }\end{array}$ \\
\hline
\end{tabular}


armed robbery, reacted firstly by describing the feelings experienced in therapy. The four major feelings that were experienced were feelings of anger, fear, sadness and peace (Marais, 2001: 40-75).

\section{Experience of anger}

A survivor of armed robbery worded his feelings as follows: "But I don't know, I have the feeling I cannot trust them. I do not know they... may be because it happened. Because I have... Jook I... in my work I must be friendly to anybody... even if they are who... when they enter I greet them... now if I know them then I ask how they are and so on... but at that moment everything was destroyed... why was I friendly to them and they treated me like this..."

Unsatisfaction with the therapist is also a reflection of anger experienced in therapy, and was verbalised as follows: "It was actually a waste of time, I felt it did not help me at all".

Therapists also experienced anger towards the robbers while the survivor is debriefed. A therapist said: "... my own reaction to what happened to him... in the sense that I became angry and upset about that what happened to him with the trauma and the unfairness and what happened to him... what was done to him and there is nothing you can do about it..."

Therapists also reflected irritation when they had to listen to the same detail over and over for the sake of therapy. A therapist said: “... I sat here at a stage and this person went on about the chain around her neck... and I nearly felt this is irrelevant... Yes it is too much detail... this was not lifethreatening..."

In the literature Kenardy, Webster, Lewin, Carr, Hazell and Carter (1996:42) reveal that $20 \%$ of people reckon after debriefing that it did not help them at all and see it as a waste of time.

\section{Experience of fear}

Participants in both groups experienced fear in therapy. Survivors would experience fear when talking about what happened as follows: "... that is now when it comes back sometimes... when I become nervous or fear or so then my whole body starts to shiver".

Fear is also experienced by the survivor of armed robbery about the process and uncertainties about therapy. A survivor says: "... so I said to him I am scared..." and "... may be I can find something about myself that I did not want to know..."

Therapists experience feelings of fear and uncertainty within therapy. A therapist verbalised: "I doubted because it was too quick for me... and you get to a stage where you feel, but now he is okay... this person's character and personality was... if I kept on hammering he would have left me totally".
Therapists also experience fear about the escalation of armed robbery and the threats it holds for them: “... you know from time to time I would wonder when will it happen to me..."

Casement (1985: 146) reflects in his notes on internal supervision: "I could feel myself becoming increasingly anxious. $I$ realised that $I$ was on the receiving end of a powerful projective identification; yet I was not sure what exactly was being put into me... I felt afraid". Peplau (1988:139) states that a therapist will find it hard to establish rapport when her own anxiety levels are too high. This will decrease her ability to concentrate and observe.

\section{Feelings of sadness}

Survivors of armed robbery experience sadness about the losses through the robbery as reflected by this 18 year old boy: "As I would ask why was my friend shot dead... one have to accept it and the Lord determined that".

Sadness is also experienced as powerlessness and disappointment when he feels that others do not understand him. A survivor of armed robbery worded it as: "My medical aid could not pay it anymore because uhh... I was promised the Bank would pay... so I had to terminate or sit with debt of two-, three thousand Rand..." and "... but it didn't really felt as if she understood me so well you know it really felt as if she wasn't really interested... she... it is just her job".

Therapists experience sadness when they feel powerless about their inability to alleviate the pain of the survivor of armed robbery as said by a therapist:"... what do you say to the person... and what consolation... what consolation do you have for this person... you know... the powerlessness that I experienced in the situation..." and also when the survivor of armed robbery does not react positive to therapy. A therapist stated:"... and to feel we were back to square one..."

Therapists experience hopelessness about the future of the country when they are too much exposed to therapy of survivors of armed robberies. A therapist said:"We are sitting in a country where people are traumatised... it is a country of shattered assumptions... these broken expectations that are only confirmed and confirmed which leads to a feeling that it is going bad and worse and then I can just expect that it will get even worse".

Dyregrov, Kristoffersen and Gjestad (1996: 552) report that therapists experience feelings of uncertainty and a feeling that life can not be predicted. These writers also note that in the case of helpers at big bus accidents, the helpers become overanxious about the safety of their relatives when they are about to use bus services.

The behaviour of survivors of armed robbery can also hurt therapists, as is the case with the following statement:"...do not come with that religious scrap to me, go away! He thus chased me away..." 


\section{Experience of peace}

Peace and satisfaction is experienced by therapists and survivors of armed robbery within therapy. A survivor reflected: “...It was not nice to talk about it, but you do feel better when you are finished... you feel more comfortable... and even more comfortable and later on you start to forget it", "... she really helped us... I must say she was very good" and: "...more or less with the third time I got a feeling of peace..."

Therapists do also experience peace and positiveness in therapy. Therapists stated:"Positive in the way that she could verbalise very well, she was anxious to verbalise..." and "...he was very aggressive about them but as time went on his attitude changed towards them because he realised... they did not partake in what happened to him". Survivors experience happiness when they start to add meaning to the crisis: “...I can say it brought me nearer to my people... can I tell you... my feelings for my wife... after what happened I felt more close to my family..."

Frankl (1979: 18-24) describes that peace is found when sense can be discovered from senseless critical situations, and names it "survival value".

The needs of survivors within therapy will now be discussed.

\section{Needs of the survivor of armed robbery within therapy}

The needs of the survivor of armed robbery that were identified by therapists and survivors themselves are needs for caring, availability, empathy, listening, focus on the armed robbery itself, help to handle problems, a trustworthy relationship with the therapist, sensitivity by the therapist and caring from important others in the life of the survivor of armed robbery. These needs will now be discussed together with verbatim quotes and appropriate literature.

\section{The need to be cared for by the therapist}

Survivors of armed robbery have a need to be cared for in therapy. If this need is not met, premature termination of therapy by the survivor of armed robbery often follows. A survivor that did not experience being cared for said: " ... it did not help much. I do feel a little bit better but that is 0.5 to 1.00 better" (Fieldnote: terminated after two sessions with different therapists).

Where caring is being experienced, therapy is seen as successful, as seen through the eyes of this survivor: "I think it was good that I went to talk to someone, somebody to who you can tell what happened and how you feels and what you must do about it and who must do what..."

Therapists also feel that caring must be given in therapy as reflected in the words of a therapist: "... and then you have a atmosphere of caring for each other and that is good for them".
Mitchell (1986b:24) explains caring within therapy as follows: "Talk to the victims. They need lots of reassurance and guidance.... When appropriate, a gentle touch of the person's hand or shoulder may be extremely helpful".

\section{Need for availability by the therapist}

Therapists for survivors of armed robberies should be available to their clients as reflected by a survivor: "Ja... she did she said that I should actually phone her... or she would phone me every two weeks..." (Fieldnote: Premature termination after one session only. No telephonic contact was made).

Therapists feel that extraordinary measures can be taken to accommodate survivors of armed robberies as said by a therapist: “...if a client do not pitch for a appointment, I phone them myself... I make a offer to have another appointment..." and "I think it can be problematic to only stick to appointments, because if there are problems you cannot see him immediately in case of a crisis".

According to Rubin (1990: 257) a team of therapists who are "genuinely committed to responding within seventy two hours of an incident" is the most successful.

\section{Need for empathy by the therapist}

Survivors of armed robbery who experience therapy as positive reflected as follows on empathy by the therapist: "And he understood what I said... and that gave me peace... that someone understands of what I am talking" and "...someone can understand what I was going through..." Therapists see empathy as one of the most important aspects in therapy, as stated by a religious therapist: “... and they will tell you they are very angry with the Lord... and that you should be able to tell them 'That is okay' ... if I can put it simple... this person needs reassurance on every level..."

A participant in a study of Robinson and Mitchell (1993:377) described the worth of empathy as follows: "Knowing that I was not alone and that we shared common feelings". Empathy is seen as one of the conditions for effective help by therapists (Manton \& Talbot, 1990:511-512).

\section{Need for listening by the therapist}

Survivors of armed robbery do have a special need to be listened to. A survivor reflected on the success of skilled listening by a therapist as follows: "And as I started to talk each time that I went there something came out... it was as if something was lifted from me"

Therapists acknowledge the worth of listening to the survivor of armed robberies with the following words: "... and many a time I just sat there and he talked... and he had the need to tell..."

McFarlane (1994: 400) words it as follows: "... the act of listening both in depth and with empathy may be the critical element in healing and this is likely to be the case par- 
ticularly with traumatised people”.

\section{Need for focus on the armed robbery}

Survivors of armed robbery feel that they went for therapy because of the robbery, therefore they need to focus on it instead of focusing on other aspects of their lives. A survivor that terminated therapy said: "Let me tell you he spoke on a lot of private things with me... this bothered me in a way, a bit"

Therapists that were participating in this study felt that the focus of therapy should be on the robbery and not on other underlying factors. A therapist's words were:"... reliving the incident...yes I focussed on that... the trauma. What do you smell what do you feel?"

Lundin (1994: 387) states it that crisis interventions must be early, short and problem focussed.

\section{Need to be helped with the handling of problems}

Survivors of armed robbery have problems to handle daily problems without help. They do have a need to get support and advice from the therapist, as reflected here: "They advised me to cry when I feel sad... If you feel like crying, then you should go somewhere and cry..."

Therapists also feel that some advice can be given to survivors of armed robbery to help them to cope with daily problems. A therapist said: "A lot of people can despite all... and they function quite normal... and then they know that when I get a nightmare, I can handle that like this..."

Duckworth (1990: 13) views practical advice on how to manage problematic situations at home and at work as psychological first aid and sees it as an essential point of departure for therapy.

\section{Need for a trustworthy relationship with the therapist}

Survivors emphasised the importance of trust in the relationship between the therapist and survivor of armed robbery. "At more or less the third time I was more at peace... it was as if I could talk immediately..."

Where trust did not exist, termination was more certain to happen for example in the case of the following experience by the survivor: "Well the guy that I actually saw didn't impress me at all..."(Fieldnote: termination of therapy after second session).

Therapists felt very strong about establishing a trustworthy relationship as worded by the following therapist: "... that initial real contact... and that the person can link with you..."

Ochberg (in Allen \& Bloom, 1994:427) states: " The therapeutic relationship must be collaborative, leading to em- powerment of one who has diminished in dignity and security..."

\section{Need for sensitivity by the therapist}

Therapists need to be sensitive to the needs of their clients, as reflected in the following statement: “ ... and I gave him a negative answer to show that I didn't want to discuss that... Then he understood I didn't want to talk about it".

Participating therapists in this study realised that they need to be sensitive to the survivor of armed robbery. A therapist said: " ... I naturally started with relaxation therapy, because he was so nervous".

Well-known therapist, Carkhuff (1969:23) states it as follows: "While structurally directful, the helping program is constantly shaped by the feedback from the helpee concerning what is effective for him".

\section{Need for care by the important others in the life of the survivor of armed robbery}

Although the need to be cared for by important others cannot be fulfilled within therapy therapists should try to help them to do so. Such an important other can be the employer who would not necessarily know what to do. The need for a better understanding and care is seen in the following words from a survivor: " ... with whom we are now, they said you can only take off such or such a time..." (Field note:Therapy terminated because off times did not suit therapist).

Rubin (1990: 257) reports that in the case where employees are allowed to have therapy in on-duty time, attendance are good and people seem to benefit by therapy.

Three principles for therapy will now be discussed.

\section{Principles for therapy Therapy should commence as soon as possible}

In interviews done for this study, both therapists and survivors of armed robberies reckoned that therapy should commence as soon as possible after exposure to the trauma of armed robbery. Therapy that commenced early thereafter was seen as more successful.

A survivor of armed robbery reflected as follows: " I went to the psychologist the next day after the robbery... I never had any nightmares or any you know any flashbacks it meant to me that therapy does work..."

A therapist's meaning on the commencement of therapy was:" It is very intensive therapy... so uhh... so as usual I do not work for very long with people, but if I can commence shortly after... while the thing is still warm... I could get away with eight sessions...uhhh if it was after some time and it became post-traumatic stress, then I would say 
I am working on a average of fifteen to eighteen sessions.

In the literature the same information was found. Emotional support and physical presence are seen as very important from the time directly after the trauma until the worst shock is over. It is said that a typical debriefing should take place within two to three days after the trauma. Individuals that were debriefed shortly after exposure are less prone to develop post- traumatic stress disorder. It is also said that interventions within 24 to 48 hours after the trauma reduce the long-term effects of the trauma (Bisson \& Deahl, 1994:717, 718; Beyers \& Joubert in Louw, 1989:152; Mitchell, 1983:36,37).

\section{The trend and technique of therapy should be discussed}

Survivors of armed robbery do not know the trend and technique of the therapy, they are influenced by previous experience and stories and may have preconceived notions based on these. All these influence their co-operation and experience. It is ideal to discuss the trend and technique of therapy with the survivor to decrease the abovementioned and anxiety due to fear of the unknown.

A survivor that terminated therapy after the first session, reflected as follows: "Well I was expecting her to ask a lot of questions and to ask how my feelings are about this and you know typical picture of a psychologist showing inkprints and stuff... but she didn't... she just asked me what happened and I told her..."

A therapist's view was: “...because you feel worse before you feel better... and a lot of people come here with the idea I'm going to become better right now... but it is them that terminate... and maybe it is someone that previously sat with the quick fix paradigm... “

Mitchell (1986b:24-25) as a expert on debriefing says: “ Tell victims what you plan to do before you do it. Surprises are not a good idea for a traumatised person who is very anxious. Discuss strategies and techniques with the victim when appropriate. Relaying summary of the plan before it is initiated can do so much to encourage co-operation from the victim".

\section{The signs and symptoms expected must be explained.}

Survivors of armed robbery have a need to know what symptoms to expect. This is the knowledge that a therapist should share and use to assure the survivor of her/his normality. When they know that all survivors would experience these symptoms, they feel at ease and do not become obsessive with their symptoms.

A survivor worded it as follows: "You talked about it and you know exactly what to expect... the symptoms you can expect... With the therapy you understand that this can happen and it is normal... you know how to handle it". A therapist reflected: "...we tell them you can expect to get nightmares... so that you basically work preventative and so that they have something to measure themselves if they are normal".

Mitchell (1986b:25) summarises it as follows: "The group leader provides reassurance that what the members of the group are experiencing is a set of normal reactions to a bad incident and that they are not going crazy".

\section{Caring for the therapist}

In this study it was clear that therapists themselves also need to be cared for. Therapists that only work with these highly traumatised survivors were traumatised themselves.

A therapist's reflection was: “... a person is naturally in such a situation as therapist also aware of how exposed we are and I think one must be careful not to become paranoid about all the things that you are exposed to..."

\section{Conclusion}

Therapists and survivors of armed robbery experience feelings of anger, fear, sadness and peace within therapy. The needs of survivors that should be met within therapy are needs to be cared for, availability of the therapist, empathy and listening by the therapist, focus on the armed robbery, help with the handling of problems, a trustworthy relationship between therapist and survivor, sensitivity from the side of the therapist and help to receive caring by the important others in the life of the survivor. The three principles of therapy identified by both groups were: therapy should commence as soon as possible after the trauma, the trend and technique of therapy should be discussed with the survivor of armed robbery and the expected signs and symptoms following this trauma have to be discussed with the traumatised.

Finally it was found that therapists dealing with this type of therapy also are in need of caring.

\section{Limitations}

Limitations were limited by using an independent coder and consultations with study leaders. The usefulness of this information is of limited worth if it is not taken further into specific guidelines for therapy.

\section{Recommendations}

Regarding promotion of better therapy for survivors of armed robbery, recommendations for nursing practice, nursing education and nursing research will now be discussed.

\section{Nursing practice}

Specific guidelines for therapy for the survivor of armed robbery should be developed through further research to make the information gained through this study useful to nursing practice. 


\section{Nursing education}

The information of the experience of therapy can be used in nursing education to teach nurse therapists about pitfalls in therapy and the needs of the survivors of armed robbery in therapy. It would make more sense if this information can be structured with specific guidelines for therapy by the nurse.

\section{Nursing research}

Further research should be done to increase the meaningfulness of this information, by testing the hypothetical worth of statements arrived at in this study.

\section{References}

ALLEN, SN \& BLOOM,SL 1994: Group and family treatment of post-traumatic stress disorder. Psychiatric Clinics of North America. 17(2), June 1994: 425-435.

BEYERS, D \& JOUBERT 1989: Posttraumatiese stresversteuring. (In: Louw DA red. 1989: Suid-Afrikaanse Handboek vir Abnormale Gedrag. Johannesburg: Southern.)

BISSON, JI \& DEAHL, MP 1994: Psychological debriefing and prevention of post-traumatic stress. British Journal of Psychiatry. 165: 717-720.

BOTHMA, S 1997: More crimes but fewer serious ones, say police. Star. 10 September 1997: 3.

CARKHUFF, RR 1969: Helping and human relations: a primer for lay professional helpers. Volume 2. New York: Rinehart \& Winston.

CASEMENT, P 1985: On learning from the patient. London: Tavistock.

DAVIS, GC \& BRESLAU, N 1994: Post-traumatic stress disorder in victims of civilian trauma and criminal violence. Psvchiatric Clinics of North America. 289-297.

DE VOS, AS \& FOUCHé, CB 1998: General introduction to research design, data collection methods and data analysis. (In: DE VOS, AS (Ed.) 1998: Research at grass roots. A primer for the caring professions. Pretoria: J L van Schaik.)

DUCKWORTH, DH 1990: Psychological trauma and the ordinary working person. Emplovee Counselling Today. 2(4): 7-13.

DYREGROV, A; KRISTOFFERSEN, JI \& GJESTAD, R 1996: Voluntary and professional disaster workers: Similarities and differences in reactions. Journal of Traumatic Stress, 9(3): 541-554.

FRANKL, VE 1979: Sê ja vir die lewe. Kaapstad: Tafelberg. HOLLWAY, W \& JEFFERSON, T 2000: Qualitative research differently. Free association narrative and the inter- view method. London: Sage.

KENARDY,JA; WEBSTER, RA; LEWIN, TJ; CARR, VJ; HAZELL, PL \& CARTER, GL 1996: Stress debriefing and patterns of recovery following a natural disaster. Journal of Traumatic Stress. 9(1): 37-49.

KREFTING, L 1991: Rigor in qualitative research: The assessment of trustworthiness. American Journal of Occupational Therapy. 45(3), March 1991: 214-222.

LINCOLN, YS \& GUBA, EG 1985: Naturalistic enquiry. London: Sage.LUNDIN, T 1994: The treatment of acute trauma. Psychiatric Clinics of North America. 0193-953X. 1994:385-391.

MANTON, M \& TALBOT, A 1990: Crisis intervention after an armed hold-up: Guidelines for counsellors. Journal of Traumatic Stress. 3(4): 507-521.

MARAIS, SJ 2001: 'n Model vir fasiliterende interaksie deur die psigiatriese verpleegkundige vir die oorlewende van gewapende roof. D.Cur (Psigiatriese Verpleegkunde) Proefskrif. Aucklandpark: RAU.

McFARLANE, A 1994: Individual psychotherapy for posttraumatic stress disorder. Psychiatric Clinics of North America. 17(2). June 1994: 393-407.

MEDICAL RESEAERCH COUNCIL nd.: Guidelines on ethics for medical research: General Priciples. Cape Town: Medical Research Council.

MITCHELL, JT 1983: When disaster strikes - the critical incident stress debriefing process. Journal of Emergency and Medical Services: volume 8, January 1983: 36-40.

MITCHELL, JT 1986 a: Assessing and managing the psychological impact of terrorism, civil disorder, disasters and mass casualties. Emergency Care Quarterly. 2(1): 51-58.

MITCHELL, JT 1986 b: Critical incident stress management. Response! September/October 1986: 24-25.

MOYA, F 1998: Hospital security guard is fed up after heist bid. Star. 21 March 1998:2.

OKUN, BF 987: Effective helping. Interviewing and counselling techniques. Monterey: Brooks/Cole.

PEPLAU, HE 1988: Interpersonal relations in nursing. A conceptual frame of reference for psychodynamic nursing. Hong Kong: Macmillan

RABIN, C \& NARDI, C 1991: Treating post-traumatic stress disorder couples: A psycho-educational program. Community Mental Health Journal. 27(3), June 1991:209. 224.

RAUTENBACH, J in RADEMEYER, A 1997: Hanteer trauma van geweld en misdaad só, sê sielkundige. Beeld. 
19 December 1997:10.

ROBINSON, RC \& MITCHELL, JT 1993: Evaluation of psychological debriefings. Journal of Traumatic Stress. 6(3): 367-382.

RUBIN, JG 1990: Critical incident stress debriefing: Helping the helpers. Journal of Emergency Nursing. Volume 16(4): 255-258.

SAPA 1998: Armed gang snatches potato truck. Star. 2 March 1998:4.

SAPA,PRETORIA CORRESPONDENT 1998: Guard shot in second attack on home. Star. 28 April 1998: 3.

SCHURINK, WJ 1998: Deciding to use a qualitative research approach and participant observation. (In: DE VOS, AS (Ed.) 1998: Research at grass roots. A primer for the caring professions. Pretoria: J L van Schaik.)

STEENKAMP,L 1999: Transitorowers maak nou só. Beeld. 10 September 1999:2.

SMITH,E 1999: Goeie nuus kom vir polisieman na jarelange wag. Rapport. 10 Oktober 1999:11.

TESCH, L in CRESWELL, JW 1994: Research design: qualitative and quantitative approaches. Thousand Oaks, California: Sage.

THIEL, G 1997: Blasting a hole in crime stats. Star. 19 September 1997:2.

VAN NIEKERK, S 1999: Buurman red bejaardes in plaasvoorval. Beeld. 24 Augustus 1999:15.

VAN WYK, A 1999: Kaapse kapers: gesin vertel van trauma. Rappport. 22 Augustus 1999: 6.

VAN ZYL, P 1999a: Skoolhoof sterf nadat hy kapers moes gaan uitken. Beeld. 3 Augustus 1999: 3.

VAN ZYL, P 1999b: Kapers spits hulle toe op Oos Rand en Pretoria. Beeld. 3 Augustus 1999: 14.

VAPI, X 1998a: Crime count and crimebusters. $\underline{\text { Star. } 11}$ March 1998:2.

VAPI, X 1998b: Crime count and crimebusters. Star. 15 March 1998:2.

WOODS, NF \& CATANZARO, M 1988: Nursing research: theory and practice. St Louis: Mosby. 